\title{
Climate Process and Change
}

\author{
By Edward Bryant \\ 1997, Cambridge University Press
}

\section{Reviewed by Larry Atkinson}

B

ryant's text starts with a Preface that I enjoyed reading. The Preface ends with a note on ages after 0 AD. Had we not been approaching $2000 \mathrm{AD}$ and had I not just listened to Stephan Jay Gould on CSPAN, I would not have known that there was no $0 \mathrm{AD}$. Our present calendar starts at $1 \mathrm{AD}$. Two memorable quotes from the Preface: "I can't help but think that climate change is not simplistic" and ". . . a small number of friends of quality is worth more than a bunch of fans or a bunch of foes (after Tazieff)."

In the Preface and Acknowledgements Bryant notes the use he made of Internet information sources. He has used those sources admirably and has done his best to reference them. One thing the Preface did not discuss was for whom the book was aimed. Although it is probably obvious to many, I always like to see whom the author at least felt he or she was focusing the book on.

The book is very well organized into the following sections:

Climate history of the Earth and background concepts

Processes

Climatic Processes

Scales of heat and mass transfers in the atmosphere

The role of the oceans

\author{
Change \\ Scales of climatic change: \\ Pleitocene to modern \\ Causes of climate change \\ Human effects on climate \\ Impacts \\ Health impacts of climate change \\ Ecosystem impacts of climate \\ change \\ Epilogue
}

While I am not a close observer of the climate change and global warming debate, I am aware that it exists, and the stakes, when national economies are considered, are high. This awareness came to me immediately as I read the first paragraph in Chapter One. The author is quite skeptical of the arguments that global warming is partly attributable to humaninduced increases in greenhouse gases. Regardless of the author's conclusion on this issue, his real mission in this book is to ". . . [present], in simple terms, the processes that drive the Earth's present climate system that are necessary for an understanding of the nature of climate change." In this regard I think he did a very good job.

The sections on Processes review all the important processes, and the sections on Change nicely present the changes that have occurred. I found the review consistently at the right level.
Throughout the book. Bryant presents himself as the skeptic. That is fine as long as the reader keeps this in mind. Bryant's thorough review of all the possible causes of global climate change in his skeptical manner provides the reader with a good sense of the contentious debate that is going on. Bryant presents some interesting and potentially provocative issues of other climate cycles, the relative importance of solar influences on the earth's heat budget, and the relative importance of the "greenhouse gases." However, I am concerned about whether a book can be both scholarly treatise and present strong opinions. I think the reader should use this book as an excellent summary of climate process and change but expand his or her view of the debate by also reading the IPCC report (1966).

The book would be appropriate for an upper level undergraduate course or lower level graduate. If more of our graduates, and scientists in general for that matter, increased their understanding of climate processes and change, the current debate might be held at a higher level.

Finally, it was refreshing as usual to read about the world from an Australian's point of view. Fortunately for most of us, he opted to use a chart projection with north at the top! 